\title{
THE NORTHERN PARULA IN MANITOBA
}

MARTIN K. McNICHOLL, 21857 - 64th Avenue, R.R. 1, Langley, British Columbia. V3A $6 \mathrm{H} 4$ and PETER TAYLOR, P.O. Box 597, Pinawa, Manitoba. ROE 1L0

The northwestern limit of the breeding range of the Northern Parula has never been well defined. The latest check-list of the American Ornithologists' Union puts it at southeastern Manitoba (Winnipeg), but the only records for that city are of migrants (see below). ${ }^{1}$ Early records indicating breeding at Waugh, Caddy Lake and McArthur Falls are not quite conclusive, as no nests or recently fledged young were found. These early records account for statements by Sprunt that the Northern Parula breeds in southeastern Manitoba, by Godfrey and by Salt and Salt that it breeds locally at Waugh, and by Bent that it breeds north to Shoal Lake (near Waugh) and Caddy Lake. 6215565 The recent discovery of at least one nest in Manitoba confirms this species' breeding status in the province.

In this paper, we review the occurrence of this attractive warbler in Manitoba, with notes on surrounding states and provinces. Recent evidence of breeding in Manitoba is presented. This article is a combination of two manuscripts written independently by the two authors and combined by McNicholl. Earlier records were compiled primarily by McNicholl, and recent material mainly by Taylor.

\section{Status in Surrounding States and Provinces}

Godfrey indicated that the breeding range of the Northern Parula (Parula Warbler) includes the more southerly parts of northwestern Ontario, although he only cites breeding localities in the central and southern portions of that province..$^{15} \mathrm{~A}$ recent annotated check- list of Ontario birds refers to it as an "uncommon local resident" across Ontario north (and west) to Kenora. ${ }^{30}$ The late A. E. Allin regarded it as rare at the Lakehead (Thunder Bay), but had several migration records there, notably several observed during an unusually heavy flight of warblers in May $1954 .^{4344454647}$ Taylor found this species to be fairly common in some mature mixed-wood stands in Sibley Provincial Park, east of Thunder Bay, in early July of 1977 and 1979 (unpublished observations).

The Parula is a regular migrant and summer resident in Minnesota, but breeding has not yet been confirmed for the northwestern part of the state, adjacent to Manitoba. ${ }^{19}$ Stewart did not include the Northern Parula in his recent book on breeding birds of North Dakota, but in an earlier checklist he classed it as a "current" species, i.e., having occurred at least three times in at least two seasons since 1920. ${ }^{64} 63$ Recent records in North Dakota include spring sightings at Jamestown in 1963, Fargo in 1968, La Moure in 1972, and Grand Forks in 1980, and a fall record in Fargo in 1975.5221296058

Sealy summarized Alberta and Saskatchewan records to $1970 .{ }^{57} \mathrm{He}$ did not include an unconfirmed record from Sovereign, Saskatchewan in 1930 and Tremaine's vague reference to seeing the species in Saskatchewan in $1965 .{ }^{33} 6^{65}$ Callin also mentioned a 1935 record at McLean, Saskatchewan. ${ }^{6}$ Tremaine's record was of a singing male watched for about 10 minutes at the Flotten Lake campground on 6 July 


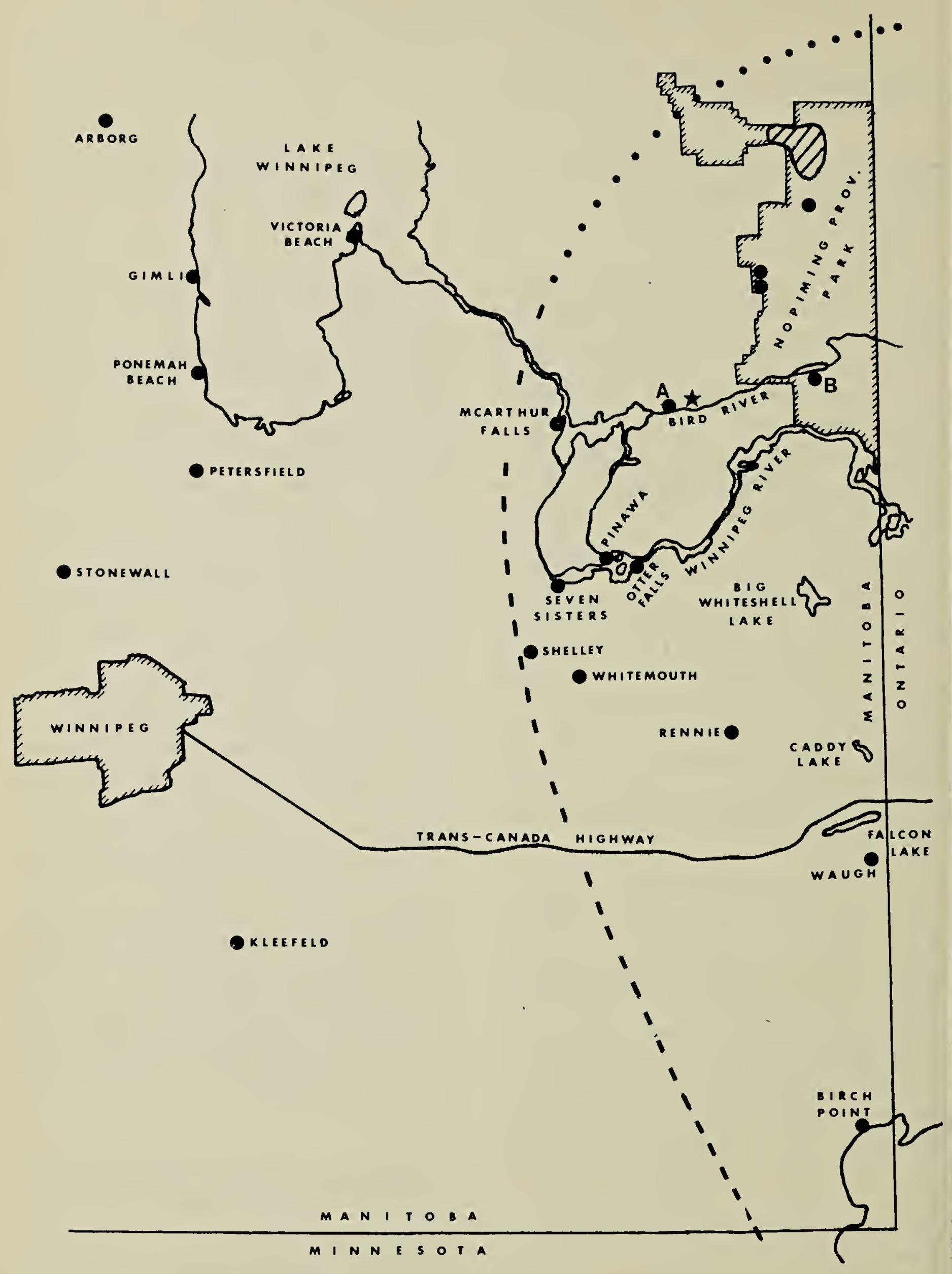

Figure 1. Map of southeastern Manitoba, showing most localities mentioned in the text (Brandon, Ninette, St. Ambroise and the International Peace Gardens are farther west). The known breeding range of the Northern Parula lies south and east of the broken line. The area north of the dotted portion is poorly known ornithologically, and the breeding range may well extend farther in this direction. 
1965 (pers. comm. to McNicholl, 14 December 1968). Although unconfirmed, this record should be considered probable in view of Dr. Tremaine's previous experience with the species and the length of observation time. Saskatchewan records since 1970 include two in Saskatoon May 1972, two males in Regina May 1979, and a singing male near Ekapo Lake May 1979.2 2961 1646 Sealy cited only one Alberta record, and Houston referred to a Calgary record in spring 1971 as
Alberta's second. ${ }^{57} 28$ However, Salt mentioned unpublished records for Wayne and Rosedale in 1958, and an August record in Calgary prior to 1971 (year not stated by Salt or his source). ${ }^{55}$ Sadler and Myres dismissed the earlier Calgary record as undocumented. ${ }^{54}$

\section{Manitoba Records Prior to 1975}

Data on records of the Northern Parula in Manitoba prior to 1975 are summarized in Table 1 and most locations are plotted on Figure 1.

Table 1. MANITOBA RECORDS OF THE NORTHERN PARULA PRIOR TO 1975

\begin{tabular}{|c|c|c|c|c|c|}
\hline Date & Locality & No. & Sex & Observer(s) & Refere \\
\hline *Sept. 1917 & Winnipeg & 1 & $\mathrm{~m}$ & J. J. Golden & 20,32 \\
\hline $\begin{array}{l}* 2 \text { or } 3 \\
\text { July } 1923\end{array}$ & $\begin{array}{l}\text { Indian Bay, } \\
\text { Shoal Lake } \\
\text { (Waugh) }\end{array}$ & $6-8$ & both & $\begin{array}{l}\text { C. R. Broley } \\
\text { C. G. Harrold } \\
\text { E. Kiteley }\end{array}$ & 20,32 \\
\hline ? 1923 & $\begin{array}{l}\text { Ponemah } \\
\text { Beach }\end{array}$ & ? & ? & "A. \& K. McL." & 31 \\
\hline 7 May 1924 & Ninette & 3 & ? & W. C. Scott & 33 \\
\hline 13 May 1926 & Ninette & $?$ & ? & R. C. Scott & 34 \\
\hline 24 May 1929 & $\begin{array}{l}\text { Victoria } \\
\text { Beach }\end{array}$ & ? & ? & E. Keighly & 36 \\
\hline 24 May 1929 & Caddy Lake & $2(+?)$ & $\mathrm{m}$ & B. W. Cartwright & 7,41 \\
\hline 19 May 1930 & Winnipeg & ? & $?$ & H. Hatton & 37 \\
\hline 20 May 1931 & Whitemouth & $?$ & $?$ & V. Latta & 38 \\
\hline 17 Sept. 1933 & Whitemouth & 1 & ? & V. Latta & 39 \\
\hline 18 May 1938 & Winnipeg & 1 & $f$ & R. Sutton & 40 \\
\hline $\begin{array}{l}\text { 16-17 June } \\
1945\end{array}$ & $\begin{array}{l}\text { McArthur } \\
\text { Falls }\end{array}$ & 2 & $\mathrm{~m}$ & $\begin{array}{l}\text { W. Johnston, } \\
\text { G. Smith }\end{array}$ & 41 \\
\hline 21 May 1946 & $\begin{array}{l}\text { McArthur } \\
\text { Falls }\end{array}$ & 1 & $\mathrm{~m}$ & W. Johnston & 41 \\
\hline $\begin{array}{l}24 \text { May to end } \\
\text { July } 1947\end{array}$ & $\begin{array}{l}\text { McArthur } \\
\text { Falls }\end{array}$ & $\begin{array}{l}2 \\
1\end{array}$ & $\begin{array}{c}m \\
f\end{array}$ & $\begin{array}{l}\text { W. Johnston } \\
\text { and father }\end{array}$ & 41 \\
\hline$? 1948$ & Petersfield & 1 & $f$ & S. Wick & 42 \\
\hline 5 June 1951 & Rennie & 1 & $\mathrm{~m}$ & W. E. Godfrey & 14 \\
\hline 1 July 1959 & Falcon Lake & 1 & $\mathrm{~m}$ & H. Mossop & 48 \\
\hline 23 May 1961 & Winnipeg & 1 & $?$ & F. J. Coutts & 49 \\
\hline 9 June 1963 & Arborg & 1 & $\mathrm{~m}$ & M. K. McNicholl & 50 \\
\hline 9 May 1964 & Winnipeg & 1 & ? & F. J. Coutts & 51 \\
\hline
\end{tabular}

*Specimen record.

June 1982. 40(2) 
Several of these are migration reports, lacking additional data and thus without corroboration. Records with additional published or unpublished information are discussed below.

Harrold stated that the first Manitoba record was of an immature bird "taken in Winnipeg" and in September 1917 by J. J. Golden. ${ }^{20}$ Golden did not collect the bird in the usual sense, but it was brought to him for identification after being found fluttering against a store window. ${ }^{32}$

The next evidence of the species in Manitoba is a vague message by Lawrence in 1923 to "A. and K. McL." of Ponemah Beach, stating that the Parula Warbler is only accidental in Manitoba; this was probably in response to a report which he doubted. ${ }^{31}$ In July of the same year, C. R. Broley, C. G. Harrold and $E$. Kitely penetrated a dense tamarack swamp, festooned with Usnea lichen, near the shores of Indian Bay on Shoal Lake near Waugh, and found what appeared to be a breeding group. 2032 Although Lawrence later credited Harrold with discovering the first nest of the species in the province, both Harrold and Lawrence himself stated that no nest was actually found; Lawrence evidently based his former statement on the presence of six to eight individuals during the breeding season. ${ }^{35204132}$ Harrold recorded the date of the visit as 3 July, Lawrence as 2 July. ${ }^{20}{ }^{32}$ Specimens of two male Parulas in the Manitoba Museum of Man and Nature, Winnipeg, were taken at Waugh by Harrold, presumably on this occasion (Specimen Nos. 758, 759).

There were three migration records in the 1920's, at Ninette and Victoria Beach (Table 1). On 25 May 1929 B. W. Cartwright found a "small colony" of Northern Parulas at Cross Lake, on the portage between Caddy and West Hawk lakes, barely on the Manitoba side of the Ontario - Manitoba border. ${ }^{7}$ According to Lawrence, Cartwright's observations consisted of two males "fighting and singing in lively fashion", behaviour which suggests that they were contesting territories. ${ }^{41}$

No additional evidence of nesting was obtained in the 1930's, but Vic Latta, the veteran nest-finder from Shelley, saw the species twice in migration near Whitemouth, and there were two migration records from Winnipeg (Table 1).

In the 1940's, two of Manitoba's most active birders obtained evidence that Parulas probably nested near McArthur Falls. Gordon Smith and Warren Johnstor found two singing males there in 1945. Johnston observed males again 21 May 1946 and 24 May 1947, and heard one or two males singing nearly every weekend in June and July in the latter year. He observed that they seemed partial to areas of tall spruce. On 8 June 1947, Johnston and his father observed a female carrying nesting material (Ref. 41 and unpublished field notes). The only migration report in the 1940's was a female in spring of Petersfield (Table 1).

In the 1950's and 1960's, the Northern Parula was seldom reported in Manitoba, but singing males were noted near Rennie in 1951, Falcon Lake in 1959, and Arborg in 1963. Winnipeg's cautious expert, Fred J. Coutts, observed spring migrants there in 1961 and 1964 (see Table 1 for sources). Mossop's observations were more significant than indicated by his passing reference to one singing in the background while he was watching a Winter Wren. ${ }^{48}$ When McNicholl reported his observation at Arborg in 1963 to Mossop, the latter indicated that he saw them regularly at Falcon Lake, near the Ontario - Manitoba border. Mossop subsequently indicated in several conversations with McNicholl that Parulas nest at Falcon Lake. 


\section{Manitoba Records, 1975-1981}

No records of Northern Parulas in Manitoba appear to have been published between 1965 and 1974 inclusive. Hatch noted that one seen in Winnipeg by Mr. and Mrs. Angus $\mathrm{H}$. Shortt 11 October 1975 was "the first record in this decade and probably much longer."22 23 Since 1975 three areas have been identified in which substantial summer populations occur. Some of these observations have been mentioned briefly in Gardner's and Hatch's newspaper columns and in seasonal regional bird reports, but most of the details are reported for the first time here. In addition, a number of records of migrants, and possibly isolated instances of breeding, have been made and are summarized in Table 2.

Numerous summer observations have been made in mature mixed-wood forest adjoining Manitoba Provincial
Road (PR) 315 near the Bird River, between Bird River campground and Bird Lake (Points $A$ and $B$ in Figure 1). The major canopy trees within Parula territories are Trembling Aspen, Balsam Poplar, White Birch, White Spruce and Balsam Fir. Usnea lichen occurs, sometimes in profusion, on dead or damaged conifers. Beaked Hazelnut and Mountain Maple are prominent understory shrubs. Typical habitat, including a nest tree, is shown in Figure 2. Between late May and early July each year from 1976 to 1981 . Parulas have been observed here by Taylor and other experienced observers (C. W. Cuthbert, D. Fast, D. R. M. Hatch, G. Holland, R. W. Knapton, R. F. Koes, W. Neily, A. H. Shortt and I. Ward), as described earlier by Hatch. ${ }^{23}$ The majority of these observations were of singing males, but females have also been seen regularly, and comprise about $15 \%$ of all records. A brief mention by Gardner of a Winnipeg sighting by Neily 2 June 1979 is referable to this area.

Table 2. RECORDS OF THE NORTHERN PARULA IN MANITOBA OUTSIDE THE THREE MAJOR KNOWN BREEDING LOCALITIES, 1975 - 1981

\begin{tabular}{|c|c|c|c|c|c|}
\hline Date & Locality & No. & Sex & Observer(s) & Reference \\
\hline 11 Oct. 1975 & $\begin{array}{l}\text { St. Vital, } \\
\text { Winnipeg }\end{array}$ & 1 & $\mathrm{~m}$ & $\begin{array}{l}\text { A. H. Shortt } \\
\text { B. Shortt }\end{array}$ & 22,23 \\
\hline 23 May 1976 & $\begin{array}{l}2 \mathrm{~km} \mathrm{~W} \text { of } \\
\text { Pinawa }\end{array}$ & 1 & m & P.Taylor & 59 \\
\hline 24 May 1976 & St. Ambroise & 1 & $\mathrm{~m}$ & $\begin{array}{l}\text { G. Grieef } \\
\text { G. Holland }\end{array}$ & $\begin{array}{l}3,9,59 \text { and } \\
\text { pers. comm. }\end{array}$ \\
\hline 23 June 1976 & $\begin{array}{l}2 \mathrm{~km} \mathrm{~W} \text { of } \\
\text { Pinawa }\end{array}$ & 1 & $\mathrm{~m}$ & P. Taylor & Unpubl. obs. \\
\hline 15 May 1977 & Gimli & 1 & $\mathrm{~m}$ & $\begin{array}{l}\text { R. W. Knapton } \\
\text { R. F. Koes }\end{array}$ & $\begin{array}{l}10,24 \text { and } \\
\text { pers. comm. }\end{array}$ \\
\hline 15 May 1977 & $\begin{array}{l}1 \mathrm{~km} \mathrm{~N} \text { of } \\
\text { Pinawa }\end{array}$ & 1 & $\mathrm{~m}$ & P. Taylor & Unpubl. obs. \\
\hline 23 May 1977 & $\begin{array}{l}1 \mathrm{~km} \mathrm{~N} \text { of } \\
\text { Pinawa }\end{array}$ & 1 & $\mathrm{~m}$ & $\begin{array}{l}\text { R. W. Knapton } \\
\text { P. Taylor }\end{array}$ & Unpubl. obs. \\
\hline 26 June 1977 & $\begin{array}{l}2 \text { and } 4 \mathrm{~km} \mathrm{NE} \\
\text { of Pinawa }\end{array}$ & 2 & $\mathrm{~m}$ & P. Taylor & Unpubl. obs \\
\hline $\begin{array}{c}\text { 10-13 Sept. } \\
1977\end{array}$ & Stonewall & 1 & $\mathrm{~m}$ & K. Gardner & 11 \\
\hline
\end{tabular}


Table 2 (continued)

\begin{tabular}{|c|c|c|c|c|c|}
\hline Date & Locality & No. & Sex & Observer(s) & Reference \\
\hline 20 Sept. 1977 & $\begin{array}{l}\text { Assiniboine } \\
\text { Park, Winnipeg }\end{array}$ & 1 & $\mathrm{~m}$ & G. Panting & 11,24 \\
\hline $\begin{array}{l}18 \text { and } 20 \\
\text { May } 1978\end{array}$ & $\begin{array}{l}\text { Near Seine } \\
\text { River, Winnipeg }\end{array}$ & 1 & $\mathrm{~m}$ & J. Loch & $\begin{array}{l}26 \text { and } \\
\text { pers. comm. }\end{array}$ \\
\hline 30 Aug. 1978 & $\begin{array}{l}\text { Big Whiteshell } \\
\text { Lake }\end{array}$ & 1 & $\mathrm{~m}$ & R. W. Knapton & Pers. comm. \\
\hline 26 May 1979 & $\begin{array}{l}2 \mathrm{~km} \mathrm{~W} \text {. of } \\
\text { Pinawa }\end{array}$ & 1 & $\mathrm{~m}$ & P. Taylor & Unpubl. obs. \\
\hline 2 June 1979 & $\begin{array}{l}3 \mathrm{~km} \mathrm{NW} \text { of } \\
\text { Pinawa }\end{array}$ & 1 & $\mathrm{~m}$ & $\begin{array}{l}\text { G. Grieef } \\
\text { P. Horch } \\
\text { I. Ward }\end{array}$ & Pers. comm. \\
\hline 25 Aug. 1979 & $\begin{array}{l}14 \mathrm{~km} \mathrm{~W} \text { of } \\
\text { Pinawa }\end{array}$ & 1 & $\begin{array}{c}\text { for } \\
\text { imm } \\
\mathrm{m}\end{array}$ & P. Taylor & Unpubl. obs. \\
\hline 9 Sept. 1979 & $\begin{array}{l}2 \mathrm{~km} N W \text { of } \\
\text { Seven Sisters }\end{array}$ & 1 & $\begin{array}{c}\text { for } \\
\text { imm } \\
\mathrm{m}\end{array}$ & P. Taylor & Unpubl. obs. \\
\hline 12 May 1980 & $\begin{array}{l}\text { Wellington Cres. } \\
\text { Winnipeg }\end{array}$ & 1 & $\mathrm{~m}$ & R. F. Koes & $\begin{array}{l}12,13,18 \text { and } \\
\text { pers. comm. } \\
\text { (cited in ref. } \\
27 \text { as } 14 \text { May) }\end{array}$ \\
\hline 13 May 1980 & Brandon & 1 & $f$ & B. Robinson & 25 \\
\hline 8 June 1980 & $\begin{array}{l}16 \mathrm{~km} \text { W of Big } \\
\text { Whiteshell Lake }\end{array}$ & 1 & $\mathrm{~m}$ & G. Grieef & Pers. comm. \\
\hline 24 Aug. 1980 & Otter Falls & 1 & $\begin{array}{c}\text { for } \\
\text { imm } \\
\mathrm{m}\end{array}$ & P. Taylor & Unpubl. obs. \\
\hline 16 May 1981 & Kleefeld & 1 & $\mathrm{~m}$ & D. Fast & Pers. comm. \\
\hline $\begin{array}{l}16 \text { May - } \\
21 \text { June } 1981\end{array}$ & Otter Falls & $\begin{array}{l}\text { up to } \\
3\end{array}$ & $\mathrm{~m}$ & $\begin{array}{l}\text { P. Taylor } \\
\text { et al }\end{array}$ & See text \\
\hline 13 June 1981 & $\begin{array}{l}\text { Big Whiteshell } \\
\text { Lake }\end{array}$ & 1 & $\mathrm{~m}$ & G. Grieef & Pers. comm. \\
\hline 26 June 1981 & $\begin{array}{l}\text { International } \\
\text { Peace Gardens }\end{array}$ & $3 ?$ & $\mathrm{~m}$ & $\begin{array}{l}\text { D. Dupre } \\
\text { et al }\end{array}$ & $\begin{array}{l}\text { Neily, } \\
\text { pers. comm. }\end{array}$ \\
\hline 27 June 1981 & $\begin{array}{l}\text { International } \\
\text { Peace Gardens }\end{array}$ & 1 & $\mathrm{~m}$ & $\begin{array}{l}\text { W. Neily } \\
\text { J. Zoch }\end{array}$ & $\begin{array}{l}\text { Neily, } \\
\text { pers. comm. }\end{array}$ \\
\hline 1 July 1981 & $\begin{array}{l}22 \mathrm{~km} \text { NE of } \\
\text { Pinawa, beside } \\
\text { PR } 313\end{array}$ & 1 & $\mathrm{~m}$ & $\begin{array}{l}\text { P.Taylor } \\
\text { L. Summers } \\
\text { J. Sunder }\end{array}$ & Unpubl. obs. \\
\hline $\begin{array}{l}16 \text { Aug. - } \\
16 \text { Sept. } 1981\end{array}$ & $\begin{array}{l}\text { Assiniboine } \\
\text { Park, Winnipeg }\end{array}$ & $\begin{array}{c}1+ \\
\text { (several } \\
\text { sightings) }\end{array}$ & $\mathrm{m}$ & $\begin{array}{l}\text { G. Grieef } \\
\text { D. R. M. Hatch } \\
\text { G. Holland } \\
\text { R. F. Koes } \\
\text { A. H. Shortt }\end{array}$ & $\begin{array}{l}\text { Grieef, Hatch, } \\
\text { Holland, Koes, } \\
\text { pers. comm. }\end{array}$ \\
\hline
\end{tabular}


The Bird River Breeding Bird Survey consists of 50 three-minute observation stops at 0.5 mile $(0.8 \mathrm{~km})$ intervals, east along PR 315 from the Bird River campground. Survey totals of Parulas between 1977 and 1981 range from five ( 8 June 1977, Cuthbert) to fourteen (17 June 1978, Taylor), with an average of 9 singing males.

A more intensive survey 19 June 1977 revealed 14 singing males between points $1 \mathrm{~km}$ west and $5 \mathrm{~km}$ east of the Bird River campground. If all singing males within $250 \mathrm{~m}$ of the road were located, and each of these represented a breeding pair, this indicates a local breeding density of about five pairs per square kilometre, corresponding to the status "common" (locally), as used by Belcher. ${ }^{4}$ The Parula was the second most numerous of ten warbler species recorded in this area on that day.

During the summer of 1977 , Cuthbert (pers. comm.) carried out a preliminary survey of breeding bird populations within Nopiming Provincial Park. He found Northern Parulas at 14 locations within an area of about 30 square kilometres near the north end of the park (shaded area in Figure 1). Pairs of birds were noted at three of these sites, and Cuthbert also found single birds at three additional localities within the park (unlabelled points in Figure 1), as well as near the Bird River. These records occurred over the period 12 May to 29 July 1977 , principally in mature mixedwood forest.

On 9 July 1977 Knapton, Koes and Taylor recorded at least 4 male and 2 female Parulas in a White Cedar Tamarack swamp and adjoining mixedwood forest and willows, at Birch Point, Lake of the Woods, in the southeastern extremity of Manitoba. Knapton and Koes briefly observed an immature bird begging for food in the willows, giving strong evidence that breeding had occurred in the vicinity. Koes and Taylor estimated 7 singing males to be present at the same location 24 June 1978, and
P. Horch and $W$. Neily reported single birds 28 June 1979 and 13 June 1981, respectively (pers. comm.). R.S. Ferguson carried out an ornithological survey in extreme southeastern Manitoba from 25 May to 7 July 1978, on behalf of the National Museum of Natural Sciences. ${ }^{8}$ He found Parulas to be "locally distributed in dense coniferous and mixed forests with a high proportion of Black Spruce, Tamarack, Eastern White Cedar or Balsam Fir." He noted singing birds on five dates between 26 May and 28 June at Birch Point and the nearby localities of Sprague Lake, Mud Lake and Angle Inlet.

Taylor has found singing male Parulas in the Pinawa - Otter Falls area on several occasions in late May and June (Table 2). In particular, up to 3 birds were observed within $1 \mathrm{~km}$ of PR 307 , south of Otter Falls between 16 May and 21 June 1981. These were again in mature mixed-wood stands with ample Usnea on some conifers. These sightings were confirmed by several other experienced observers: $A$. Blewett, N. J. Cleveland, Fast, Hatch and Lane.

An especially interesting record of the Northern Parula occurred recently at the International Peace Gardens, on the North Dakota - Manitoba border in southwestern Manitoba. Here, Delos Dupre and several other visitors to the province, who were participating in a field trip organized by the North American Bluebird Conference in Brandon, reported 3 singing birds 26 June 1981. Two Manitoba birders, Neily and $\mathrm{J}$. Zoch, confirmed this report in part when they found a single singing male the following day.

\section{Evidence of Breeding}

Irregular early reports and regular recent observations of singing male Parulas in appropriate breeding habitat from late May to July, together with a 
smaller number of sightings of the less conspicuous females, provide strong evidence in support of Lawrence's suggestion that this bird is a locally common breeding species in southeastern Manitoba. ${ }^{41}$

The Parula is noted for its strong affinity for arboreal mosses and lichens. ${ }^{52}$ Lichens of the genus Usnea are used for nesting in the northern part of the breeding range, and are commonly reported at sites of suspected breeding in Manitoba, as noted above. This lichen was common in the vicinity of the singing male seen at Arborg by McNicholl.

The best early evidence of breeding is Johnston's observation of a female carrying nesting material near McArthur Falls in 1947. On 22 May 1978 Holland, Ward and Taylor visited the Bird River area. Ward saw a female Parula enter a clump of Usnea about $10 \mathrm{~m}$ up in a white spruce. All three observers saw the bird emerge about a minute later; she was evidently at least prospecting for nest sites, and may well have been building a nest. However, no activity was observed at this site during two subsequent visits in June, so breeding could not be confirmed. The same observers and $P$. Press made similar observations at a location about $25 \mathrm{~km}$ farther east, at the junction of PR 315 and Bird Lake Block Road number 10 on 8 June 1980.

An active nest was finally located by Taylor 7 July 1979 in a clump of Usnea about $8 \mathrm{~m}$ up in a storm-damaged white spruce, very close to the suspected nest-site of 1978 (Figures 2 and 3). During about 45 minutes of observation in the early morning, the female visited the nest with food five times, indicating that young were present. She also settled on the nest to brood briefly during this period. On one occasion she foraged in the understory nearby after feeding the young, but she usually departed into the canopy following visits to the nest. This is the nest cited as "northeast of Lac du Bonnet" by Gollop. ${ }^{17}$

Although there is only this one definitive nest record for Manitoba, the many observations detailed above all

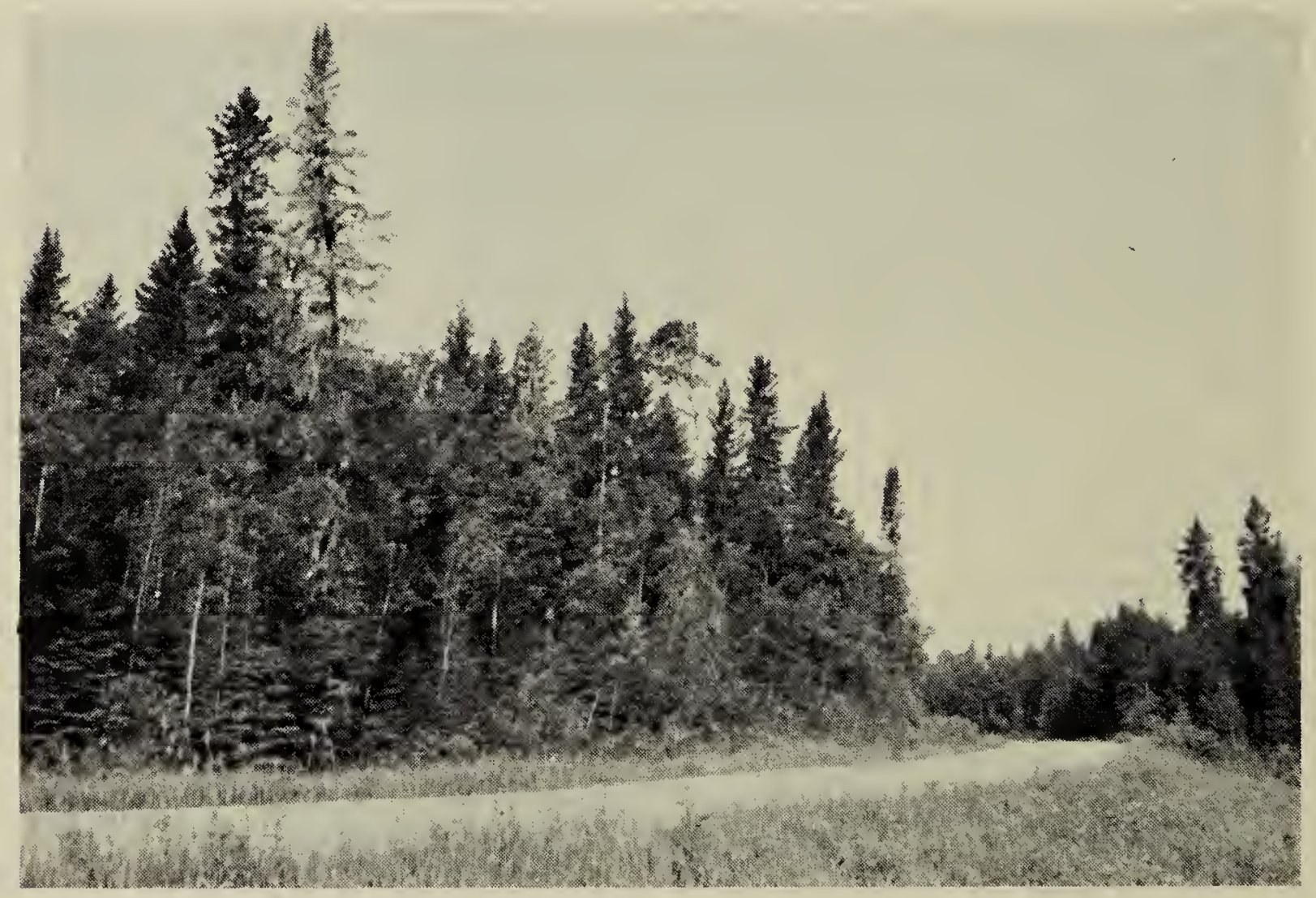

Figure 2. Location of the 1979 Parula nest alongside PR 315. This mature mixed-wood stand is typical of Parula breeding habitat in this area. 
ANONYMOUS. 1976. Bird report for month of May. Man. Nat. Soc. Bull. July-Aug. 1976: 7-8.

${ }^{4}$ BELCHER, M. 1980. Birds of Regina. Revised ed. Sask. Nat. Hist. Soc. Spec. Publ. No. 12.

${ }^{5}$ BENT, A. C. 1953. Life histories of North American wood warblers. U.S. Natl. Mus. Bull. 203 (Dover ed. 1963).

${ }^{6}$ CALLIN, E. M. 1980. Birds of the Qu'Appelle, 1857-1979. Sask. Nat. Hist. Soc. Spec. Publ. No. 13.

CARTWRIGHT, B.W. 1931. Notes and observations on some Manitoban birds. Can. Field-Nat. 45: 181-187.

${ }^{8}$ FERGUSON, R. S. 1981. Summer birds of the Northwest Angle Provincial Forest and adjacent Southeastern Manitoba. Syllogeus No. 31. Natl. Mus. Can.

${ }^{9}$ GARDNER, K. 1976. (Untitled). Wild Wings. Winnipeg Tribune. 12 June 1976.

${ }^{10}$ GARDNER, K. 1977a. Wild Wings. Winnipeg Tribune. 18 June 1977.

1 GARDNER, K. 1977b. Varied Thrush now seen regularly. Wild Wings. Winnipeg Tribune. 15 October 1977.

12 GARDNER, K. 1980a. Rare birds sightings increase. Wild Wings. Winnipeg Tribune. 24 May 1980.

${ }^{13}$ GARDNER, K. 1980b. Migration reports. Wild Wings. Winnipeg Tribune. 31 May 1980.

${ }^{14}$ GODFREY, W. E. 1953. Notes on birds of the area of intergradation between eastern prairie and forest in Canada. Natl. Mus. Canada Bull. No. 128: 189240.

${ }^{15}$ GODFREY, W. E. 1966. The birds of Canada. Natl. Mus. Canada Bull. No. 203.

${ }^{16}$ GOLLOP, J.B. 1979a. The spring migration. March 1 - May 31, 1979. Prairie provinces region. Amer. Birds 33: 781-782.

${ }^{17}$ GOLLOP, J. B. 1979b. The nesting season. June 1 - July 31, 1979. Prairie provinces region. Amer. Birds 33: $872-$ 873.

${ }^{18}$ GOLLOP, J.B. 1980. The spring migration. March 1 - May 31, 1980. Prairie provinces region. Amer. Birds 34: 787-789.
${ }^{19}$ GREEN, J. C. and R. B. JANSSEN. 1975.

Minnesota birds: where, when and how many. Univ. Minnesota Press, Minneapolis.

${ }^{20}$ HARROLD, C. G. 1923. Notes on some interesting species. Can. Field-Nat. 37: 169.

${ }^{21}$ HATCH, D. R. M. 1968. Spring migration. April 1 - May 31, 1968. Northern Great Plains region. Audubon Field Notes 22: 544-547.

${ }^{22}$ HATCH, D. 1975. Chickadee Notes No.98. Winnipeg Free Press 29 November 1975.

${ }^{23} \mathrm{HATCH}$, D. 1976. (Untitled). Chickadee Notes No. 132. Winnipeg Free Press. 24 July 1976.

${ }^{24}$ HATCH, D. 1977. Chickadee Notes. Winnipeg Free Press 1 October 1977.

${ }^{25} \mathrm{HATCH}$, D. 1980. Keep cards coming. Chickadee Notes. Winnipeg Free Press 20 June 1980.

${ }^{26} \mathrm{HORCH}, \mathrm{P}$. 1978. Bird news. Man. Nat. Soc. Bull. 1(11): 11.

${ }^{27} \mathrm{HORCH}$, P. 1980. Bird news. Man. Nat. Soc. Bull. 3(10): 12-13.

${ }^{28}$ HOUSTON, C. S. 1971. The nesting season. June 1, 1971 to August 15, 1971. Northern Great Plains region. Amer. Birds 25: 869-872.

${ }^{29}$ HOUSTON, C. S. 1972. The spring migration. April 1 to May 31, 1972. Northern Great Plains. Amer. Birds 26: 774-777.

30 JAMES, R.D., P. L. MCLAREN, and J. C. BARLOW. 1976. Annotated checklist of the birds of Ontario. Royal Ont. Mus. Misc. Publ., Toronto.

${ }^{31}$ LAWRENCE, A. G. 1923a. Breeding notes. Chickadee Notes No. 113. Winnipeg Free Press 24 May 1923.

${ }^{32}$ LAWRENCE, A. G. 1923b. The Northern Parula Warbler. Chickadee Notes No. 119. Winnipeg Free Press 5 July 1923.

${ }^{33}$ LAWRENCE, A. G. 1924. Northern Parula Warbler. Chickadee Notes No. 166. Winnipeg Free Press 29 May 1924.

${ }^{34}$ LAWRENCE, A. G. 1926. Migration records. Chickadee Notes No. 268. Winnipeg Free Press 13 May 1926.

${ }^{35}$ LAWRENCE, A. G. 1929a. Cyril Guy 
Harrold. Chickadee Notes No. 415. Winnipeg Free Press 19 March 1929.

6 LAWRENCE, A. G. 1929b. Migration records. Chickadee Notes No. 428. Winnipeg Free Press 6 June 1929.

${ }^{37}$ LAWRENCE, A. G. 1930. Migration records. Chickadee Notes No. 479. Winnipeg Free Press 30 May 1930.

${ }^{38}$ LAWRENCE, A. G. 1931. Migration notes. Chickadee Notes No. 531. Winnipeg Free Press 29 May 1931.

LAWRENCE, A. G. 1933. Rarities at Whitemouth. Chickadee Notes No. 655. Winnipeg Free Press 13 December 1933.

${ }^{40}$ LAWRENCE, A. G. 1938. Migration notes. Chickadee Notes No. 895. Winnipeg Free Press 20 May 1938.

${ }^{41}$ LAWRENCE, A. G. 1947. A gorgeous summer resident of the muskeg. Chickadee Notes No. 1377. Winnipeg Free Press 10 October 1947.

LAWRENCE, A. G. 1948. Migration reports. Chickadee Notes No. 1409. Winnipeg Free Press 21 May 1948.

${ }^{43}$ LAWRENCE, A. G. 1951a. Wave of migrants hits Lakehead. Chickadee Notes No. 1566. Winnipeg Free Press 25 May 1951.

${ }^{44}$ LAWRENCE, A. G. 1951b. Migration reports. Chickadee Notes No. 1567. Winnipeg Free Press 1 June 1951.

${ }^{45}$ LAWRENCE, A. G. 1954a. Great wave of migrants. Chickadee Notes No. 1724. Winnipeg Free Press 4 June 1954

${ }^{46}$ LAWRENCE, A. G. 1954b. Unusual numbers of rarities. Chickadee Notes No. 1726. Winnipeg Free Press 18 June 1954.

${ }^{47}$ LAWRENCE, A. G. 1954C. A review of the unusual. Chickadee Notes No. 1729. Winnipeg Free Press 9 July 1954.

${ }^{48}$ MOSSOP, H. 1959. The Winter Wren sings. Chickadee Notes No. 237. Winnipeg Free Press 31 July 1959.

${ }^{49}$ MOSSOP, H. 1961. Migration reports. Chickadee Notes No. 331. Winnipeg Free Press 20 May 1961.

${ }^{50}$ MOSSOP, H. 1963. Migration reports.
Chickadee Notes No. 439. Winnipeg Free Press 15 June 1963.

${ }^{51}$ MOSSOP, H. 1964. Migration reports. Chickadee Notes No. 487. Winnipeg Free Press 16 May 1964.

${ }^{52}$ NERO, R. W. 1963. Spring migration. April 1 to May 31, 1963. Northern Great Plains region. Audubon Field Notes 17: 412-414.

${ }^{53}$ ROY, J. F. 1964. Birds of the Elbow. Sask. Nat. Hist. Soc., Regina.

${ }^{54}$ SADLER, T. S., and M. T. MYRES. 1976. Alberta birds 1961-1970. Prov. Mus. Alberta, Nat. Hist. Sec. Occas. Pap. No. 1.

${ }^{55}$ SALT, W. R. 1973. Alberta vireos and wood warblers. Prov. Mus. and Archives of Alberta Publ. No. 3.

${ }^{56}$ SALT, W. R., and J. R. SALT. 1976. The birds of Alberta with their ranges in Saskatchewan and Manitoba. Hurtig. Edmonton.

${ }^{57}$ SEALY, S. G. 1970. Records of the Parula Warbler in Alberta and Saskatchewan. Blue Jay 28: 164-166.

${ }^{58}$ SERR, E. M. 1976a. The fall migration. August 1 - November 30, 1975. Northern Great Plains. Amer. Birds 30: 87-90.

${ }^{59}$ SERR, E. M. 1976b. The spring migration. April 1 - May 31, 1976. Northern Great Plains. Amer. Birds 30: 855-858.

${ }^{60}$ SERR, E. M. 1980. The spring migration. March 1 - May 31, 1980. Northern Great Plains. Amer. Birds 34: 789-791.

61 SHADICK, S. 1975. Highlights of Saskatoon bird observations 19701974. Blue Jay 33: 165-168.

${ }^{62}$ SPRUNT, A., Jr. 1979. Parula Warbler. pp. 68-69 in L. Griscom and A. Sprunt, Jr. (Editors). The warblers of America. Revised and updated by E. M. Reilly, Jr. Doubleday, New York.

${ }^{63}$ STEWART, R. E. 1971. Check list of birds in North Dakota. Prairie Nat. 3: 3-12.

${ }^{64}$ STEWART, R. E. 1975. Breeding birds of North Dakota. Tri-College Center for Environ. Studies, Fargo.

65 TREMAINE, M. M. 1966. Saskatchewan revisited. Blue Jay 24: 182-183. 